\title{
Toe-extension myotonia in myotonic dystrophy type 1
}

回

Supplemental data at Neurology.org
Myotonia is a cardinal symptom of adult-onset myotonic dystrophy type 1 (DM1). Myotonia, delayed relaxation following contraction, is most prominent in the hand and forearm muscles. Two sisters with genetically confirmed DM1 exhibited toe-extension myotonia (video on the Neurology ${ }^{\circledR}$ Web site at Neurology.org) in contrast to toe-flexion myotonia that can occur in DM1. There was a typical warm-up phenomenon. A variant phenotype of Charcot-Marie-Tooth-like polyneuropathy ${ }^{1}$ was not present. Mutations in the CLCN1 gene encoding the skeletal muscle chloride channel, in addition to abnormal splicing, can enhance myotonia in DM type $2 .^{2}$ However, in our patients sequencing of the CLCN1 gene did not show mutations.

Ami Mankodi, MD, Christopher Grunseich, $M D$

From the Neurogenetics Branch, National Institute of Neurological Disorders and Stroke, Bethesda, MD.

Acknowledgment: The authors thank Drs. Thornton and Moxley (University of Rochester, NY) for discussions; and Hirity Shimellis, Angela Kokkinis, and Dara Bakar for help with patient care and making of the video.

Study funding: Supported by intramural funding from the NIH.

Disclosure: The authors report no disclosures relevant to the manuscript. Go to Neurology.org for full disclosures.

Correspondence to Dr. Mankodi: ami.mankodi@nih.gov

1. Braida C, Stefanatos RK, Adam B, et al. Variant CCG and GGC repeats within the CTG expansion dramatically modify mutational dynamics and likely contribute toward unusual symptoms in some myotonic dystrophy type 1 patients. Hum Mol Genet 2010;19:1399-1412.

2. Suominen T, Schoser B, Raheem O, et al. High frequency of co-segregating CLCN1 mutations among myotonic dystrophy type 2 patients from Finland and Germany. J Neurol 2008;255:1731-1736.

\section{Enjoy Neurology ${ }^{\circledR}$ Clinical Practice on your iPad ${ }^{\circledR}$}

The same information so critical to your practice is now brought to you on the iPad ${ }^{\circledR}$. This dynamic app optimizes the best in digital technology to enhance the reading experience with article-sharing features, multimedia, links, and more.

Enjoy the benefits:

- Easy-to-read articles you can share via email and social media

- Adjustable text sizing with "pinch and zoom" technology

- Engaging multimedia videos, images, and data supplements

- Ability to store downloaded issues

- Convenient notification when a new issue is available

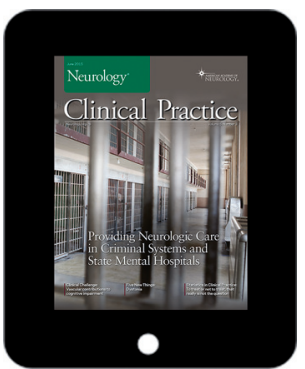

AAN members - enjoy Full Access to every issue on your iPad ${ }^{\circledR}$. If you are not yet a member, download the app and GET THE LATEST ISSUE FREE! (Go to http://bit.ly/NCPapp for details.) 


\section{Neurology}

\section{Toe-extension myotonia in myotonic dystrophy type 1 \\ Ami Mankodi and Christopher Grunseich \\ Neurology 2015;85;203 \\ DOI 10.1212/WNL.0000000000001734}

\section{This information is current as of July 13, 2015}

\section{Updated Information \& Services}

\section{Supplementary Material}

\section{References}

Subspecialty Collections

\section{Permissions \& Licensing}

Reprints including high resolution figures, can be found at: http://n.neurology.org/content/85/2/203.full

Supplementary material can be found at: http://n.neurology.org/content/suppl/2015/07/11/WNL.0000000000001 734.DC1

This article cites 2 articles, 0 of which you can access for free at: http://n.neurology.org/content/85/2/203.full\#ref-list-1

This article, along with others on similar topics, appears in the following collection(s):

\section{All Clinical Neurology}

http://n.neurology.org/cgi/collection/all_clinical_neurology

All Neuromuscular Disease

http://n.neurology.org/cgi/collection/all_neuromuscular_disease

\section{Clinical neurology examination}

http://n.neurology.org/cgi/collection/clinical_neurology_examination

Muscle disease

http://n.neurology.org/cgi/collection/muscle_disease

Information about reproducing this article in parts (figures,tables) or in its entirety can be found online at:

http://www.neurology.org/about/about_the_journal\#permissions

\section{Information about ordering reprints can be found online:}

http://n.neurology.org/subscribers/advertise

Neurology ${ }^{\circledR}$ is the official journal of the American Academy of Neurology. Published continuously since 1951, it is now a weekly with 48 issues per year. Copyright (C 2015 American Academy of Neurology. All rights reserved. Print ISSN: 0028-3878. Online ISSN: 1526-632X.

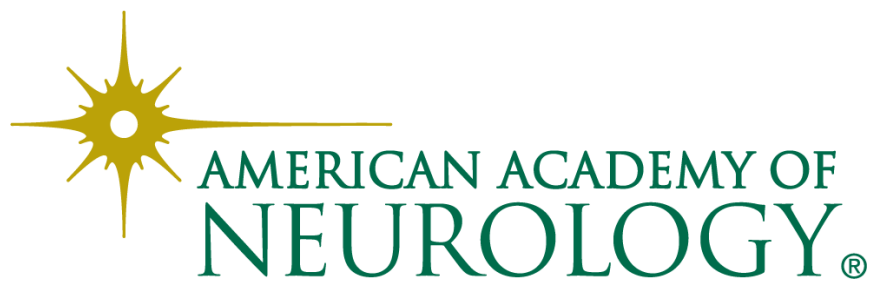

